\title{
Lineage-specific Gene Expression in the Sea Urchin Embryo
}

\author{
E.H. Davidson, C.N. Flytzanis, J.J. LeE, J.J. Robinson, S.J. Rose III, AND H.M. SuCOV \\ Division of Biology, California Institute of Technology, Pasadena, California 91125
}

Within a few days of fertilization, the sea urchin embryo develops into a small differentiated organism consisting of about 1800 cells and capable of feeding, swimming, and the further ontogenic transformations required in the succeeding weeks of larval growth. A number of distinct cell lineages that are clearly specialized at the morphological and functional levels can be discerned in the advanced embryo, and many of these can be traced back to particular sets of early blastomeres. Classical cell lineage and experimental studies (Hörstadius 1939; for review, see Angerer and Davidson 1984) have shown that certain of these lineages appear to be specified, at least in part, in consequence of the maternal components inherited in those regions of egg cytoplasm occupied by their progenitor cells. Specification of others among the early cell lineages clearly depends on inductive interactions that occur between blastomeres during cleavage. For the molecular biologist, as for his predecessors, this rapidly developing and simply constructed embryo offers the advantages of experimental accessibility. Thus, in respect to direct molecular-level analyses of gene activity in the embryo, for both specific genes and overall transcript populations and their protein products, the sea urchin is at present the best known embryonic system (e.g., reviews of Hentschel and Birnstiel 1981; Davidson et al. 1982; Angerer and Davidson 1984).

A focus of recent efforts in our laboratory has been the acquisition of a library of cloned genes that are expressed in the early embryo in a lineage-specific manner, for use in examination of the molecular processes by which these genes are differentially specified for activity early in development. This is, of course, the fundamental and general problem in understanding how the zygote gives rise to a functionally differentiated embryo, even given the well-established cytoplasmic anisotropy of most eggs (reviewed by Davidson 1976). It is a problem that is far from being solved for any embryo. Furthermore, diverse solutions may well be utilized in different modes of development. In the following, we review current progress on the isolation and characterization of lineage-specific sea urchin embryo genes, and then describe briefly recent studies that demonstrate apparently correct ontogenic expression of such genes after microinjection into the unfertilized egg.

\section{The Sea Urchin Actin Genes}

There are eight actin genes per haploid genome in Strongylocentrotus purpuratus, of which two are prob- ably pseudogenes (Lee et al. 1984). All of the remaining six are expressed in the embryo. Of these, one is a muscle actin gene (M) and the others code for cytoskeletal (Cy) actin proteins (Durica et al. 1980; Scheller et al. 1981; Lee et al. 1984; Shott et al. 1984). Contrary to the implication of the cliche that cytoskeletal actin genes are "housekeeping" genes, our analysis of the patterns of expression of the individual members of this gene family has shown that each gene is expressed according to a specific ontogenic program. The genomic linkages of these genes, the nomenclature by which they are designated, and their patterns of activity in embryo and adult cell types, are summarized in Figure 1. Although their protein-coding regions are largely homologous, these genes differ greatly in the $3^{\prime}$ nontranslated trailer sequences of their mRNAs (Scheller et al. 1981; Lee et al. 1984), and this affords a means of preparing gene-specific molecular probes to identify their transcripts individually. Such probes have been utilized in RNA gel blot and in situ hybridization studies for determining the spatial and temporal patterns of actin gene expression in the embryo (Angerer and Davidson 1984; Shott et al. 1984; K.H. Cox et al., in prep.). As indicated in Figure 1 the expression of several of the actin genes is strictly lineage specific, and none is active ubiquitously. For example, it is shown in Figure 2 that transcripts of the $M$ actin gene are confined to two bilateral patches, each containing 10-20 cells that are associated with the newly formed coelomic pouches in the late embryo. These cells are of the secondary mesenchyme cell lineage, and their role is the construction of the pharyngeal muscle required for larval feeding. Expression of the CyIIIa and CyIIIb cytoskeletal actin genes is also confined to a single embryonic cell lineage, although CyllIa messages are present as well in maternal RNA at the low level of about 1200 molecules per egg (J.J. Lee et al., unpubl.). They are not spatially localized in the egg (K.H. Cox et al., in prep.). After fertilization, newly synthesized transcripts of the CyIIIa and CyIIIb actin genes appear only in aboral ectoderm cells, although on different schedules. An in situ hybridization experiment carried out with a CyIIIa probe that demonstrates the early localization of these transcripts is shown in Figure 3 (Angerer and Davidson 1984; K.H. Cox et al., in prep.).

Expression of the Cylla gene is restricted to mesenchyme cells, and in late embryos to parts of the gut. The CyI and Cyllb genes are regulated similarly to one another, and their transcripts are more widely distributed than those of the other actin genes. These messages are also found in small quantities in the unfertil- 


\begin{tabular}{|c|c|c|c|c|c|c|}
\hline & $5^{\prime}$ & $\overrightarrow{C y I}$ & $5^{\prime}$ & $\overrightarrow{C y \| a}$ & & $\overrightarrow{\mathrm{Cy} \| \mathrm{b}}$ \\
\hline \multirow[t]{2}{*}{ Embryo } & early & $\begin{array}{l}\text { all regions of blastulo } \\
\text { mesenchyme cells }\end{array}$ & early & mesenchyme cells & early & $\begin{array}{l}\text { all regions of blastulo } \\
\text { mesenchyme cells }\end{array}$ \\
\hline & late & $\begin{array}{l}\text { oral (not abora!) ectoderm } \\
\text { gut }\end{array}$ & late & regions of gut & tote & $\begin{array}{l}\text { oral (not aboral) ectoderm } \\
\text { gut }\end{array}$ \\
\hline Adult & $\begin{array}{l}\text { intes } \\
\text { tubef } \\
\text { coelo } \\
\text { lante }\end{array}$ & $\begin{array}{l}\text { ine } \\
\text { not } \\
\text { nocyte } \\
\text { muscle }\end{array}$ & \multicolumn{2}{|c|}{$\begin{array}{l}\text { intestine } \\
\text { coelomocyte }\end{array}$} & \multicolumn{2}{|c|}{$\begin{array}{l}\text { intestine } \\
\text { tubefoot }\end{array}$} \\
\hline
\end{tabular}

Embryo
Adult
aborol ectoderm only

Embryo

Probable unlinked pseudogenes:

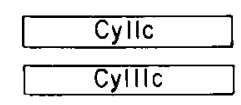

Figure 1. Organization and expression of actin gene family in the sea urchin $S$. purpuratus. Actin genes are named $\mathrm{M}$ (muscle) or $\mathrm{Cy}$ (cytoskeletal, i.e., expressed in nonmuscle cell types). Roman numerals designate the three nonhomologous $\mathbf{3}^{\prime}$ nontranslated trailer sequences found in the cytoskeletal actin genes. a, b, and c designate different though homologous trailer sequence variants. Linkage data are from analyses of cloned genes (Lee et al. 1984; R. Akhust, F. Calzone, R. Britten, and E. Davidson, in prep.). Expression patterns in adult tissues were determined by RNA gel blot hybridizations, as reported by Shott et al. (1984). Expression of actin genes in embryonic cell types is summarized from the in situ hybridization study of $\mathrm{K}$.H. Cox et al. (in prep.).

ized egg, and both genes are then expressed in all regions of the early embryo. However, in the ectoderm of pluteus-stage embryos, the pattern of expression is exactly complementary to that of CyIIIa, as their messages are located in the oral but not in the aboral ectoderm. Thus, except for CyI and CyIIb, which function similarly, each of the actin genes is utilized in a particular set of cells at particular times during embryogenesis and it may be supposed that each possesses its own unique cis-regulatory genomic control apparatus.

The number of mRNA molecules produced during embryonic development by five of the six functional actin genes has recently been measured by J.J. Lee et al. (unpubl.). These estimates were obtained by a single-strand probe excess titration method (Wallace et al. 1977; Scheller et al. 1978; Lev et al. 1980) using RNA transcripts synthesized in vitro from an Sp6 promoter (Butler and Chamberlin 1982; Melton et al. 1984). Since the cell types in which the various actin genes are expressed are known, the number of molecules of each mRNA species per active cell can be calculated from these data. These results are summarized in Table 1.

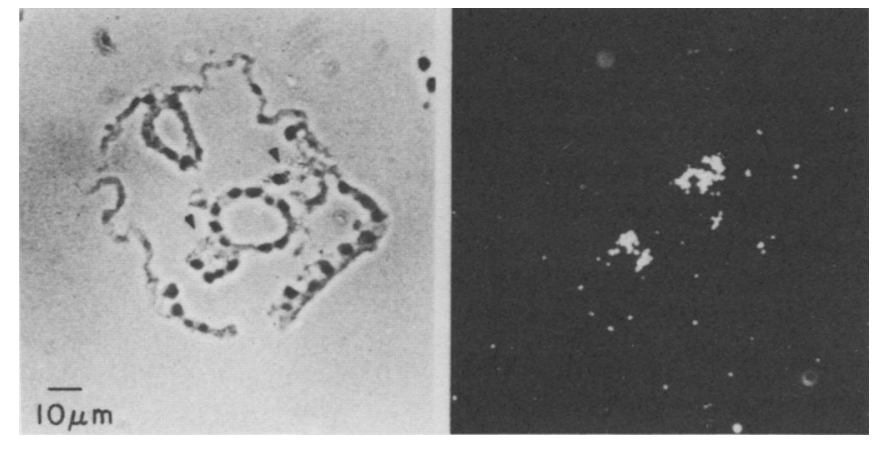

Figure 2. Expression of $M$ actin gene in bilateral pharyngeal muscle anlage cells, visualized by in situ hybridization. Phase photomicrograph of embryo, an 82-hr pluteus, is shown at the left. (Reprinted, with permission, from K.H. Cox, L.M. Angerer, J.J. Lee, E.H. Davidson, and R.C. Angerer, in prep.) 


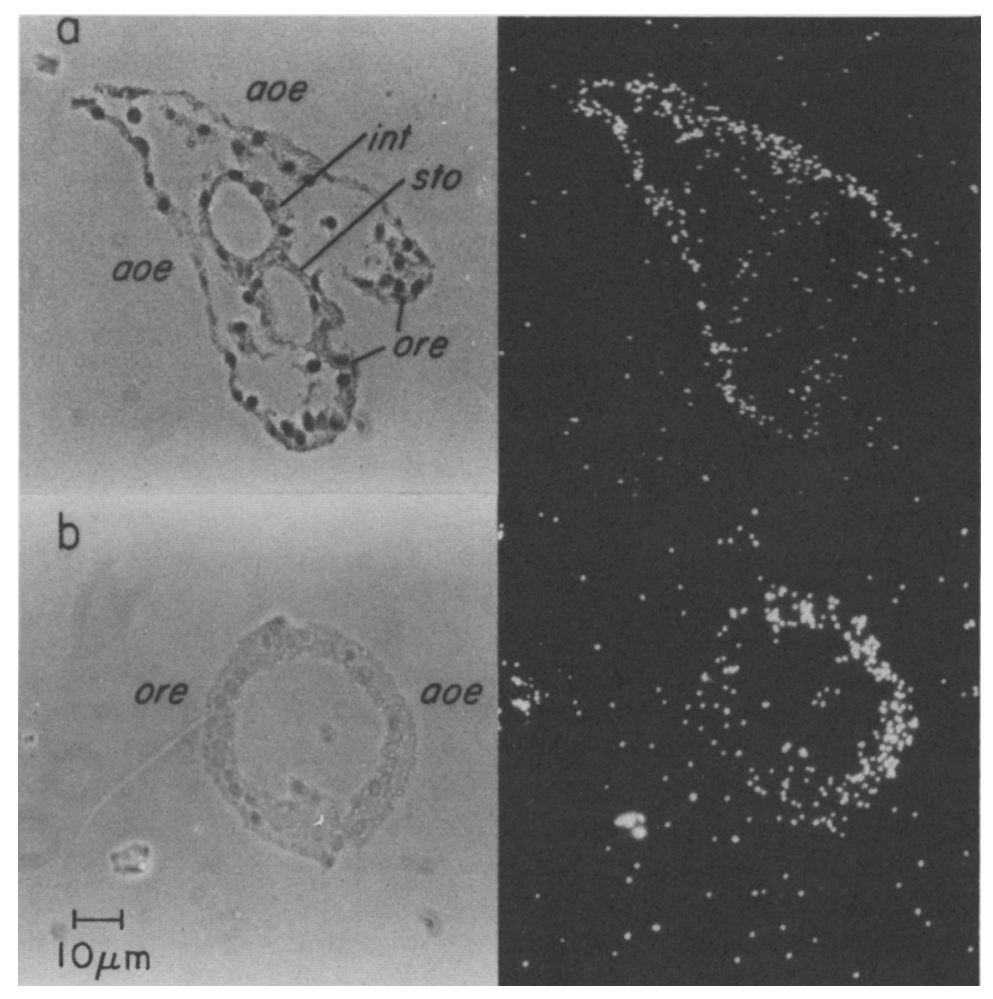

Figure 3. Expression of CylIIa actin gene in aboral ectoderm of pluteus-stage embryo (a) and of blastula (b) visualized by in situ hybridization. Labeling in other regions is at background level, as shown by control experiments with probes that are not represented in sea urchin RNA. Phase photomicrographs $(l e f t)$ : aoe, aboral ectoderm; int, intestine; sto, stomach; ore, oral ectoderm. (Reprinted, with permission, from Angerer and Davidson 1984.)

Gene transfer experiments described briefly in a following section of this report have focused on the $\mathrm{Cy}$ IIIa actin gene. This is the single most intensely expressed of all the actin genes in the embryo and its activity is confined to embryonic and larval stages. Thus, it is not utilized at all in the postmetamorphosis sea urchin (Shott et al. 1984). As shown in Table 1, late in embryogenesis there are about 200 molecules of CyIIIa mRNA per aboral ectoderm cell. The time course of Cyllla gene expression during eariy development, as established by titration measurements, is shown in Figure 4. Within a few hours beginning at the very early blastula stage, new transcripts of this gene appear, and they accumulate dramatically to a level of over 80,000 molecules per embryo. Nuclear run-off experiments (S. Johnson, R. Britten, and E. Davidson, unpubl.) indicate that this accumulation is regulated primarily at the transcription level.

\section{Other Lineage-specific Cloned Genes Active in the Sea Urchin Embryo}

Two other sea urchin genes that, like the CyllIa and CyIIIb actin genes, are expressed specifically in aboral ectoderm have been characterized by Dr. William Klein and his associates (Bruskin et al. 1981, 1982; Lynn et al. 1983; Carpenter et al. 1984; S.L. Houck, C.D. Carpenter, P.E. Hardin, A.M. Bruskin, and W.H. Klein, unpubl.). These genes, called Spec1 and Spec2 (Spec, $S$. purpuratus ectoderm), code for intracellular $\mathrm{Ca}^{++}$ binding proteins related to troponin $\mathrm{C}$. The aboral ec-

Table 1 Transcripts per Cell for Five Actin Genes Expressed in the Embryo of $S$. purpuratus

\begin{tabular}{lccc}
\hline Gene & $\begin{array}{c}\text { Approximate number of } \\
\text { cells transcribing actin } \\
\text { mRNA per embryo }\end{array}$ & $\begin{array}{c}\text { Number of actin } \\
\text { transcripts per } \\
\text { embryo }\end{array}$ & $\begin{array}{c}\text { Number of actin } \\
\text { transcripts per } \\
\text { expressing cell }\end{array}$ \\
\hline CyI & 1000 & $9 \times 10^{4}$ & 90 \\
CyIIa & 160 & $1.4 \times 10^{4}$ & 90 \\
CyIIb & 1000 & $5.8 \times 10^{4}$ & 60 \\
CyIIIa & 470 & $8.8 \times 10^{4}$ & 190 \\
M & $20-40$ & $2.5 \times 10^{4}$ & $650-1300$ \\
\hline
\end{tabular}

Data are from J.J. Lee, F.J. Calzone, R.J. Britten, R.C. Angerer, and E.H. Davidson (unpubl.); measurements refer to 65 -hr pluteus-stage embryos. 


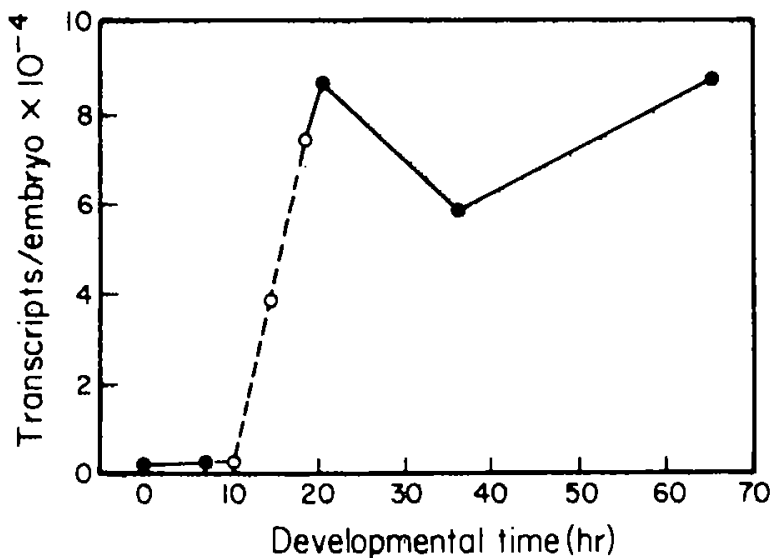

Figure 4: Quantities of Cyllla actin gene transcripts accumulated during embryonic development. Transcripts were measured by solution titration with excess single-strand complementary probes. Various quantities of whole-embryo RNA were reacted with a gene-specific RNA probe synthesized in vitro. The shape of the curve for the dashed line is derived from relative RNA gel blot data (Shott et al. 1984) (open circles). Titration measurements are designated by closed circles.

toderm descends initially from one animal pole quadrant of the cleavage-stage blastomeres, and its differentiation thus involves the activation in this lineage of a whole battery of diverse genes. This battery may include many other genes in addition to the examples already known, i.e., Spec1, Spec2, CyIIIa, and CyIIIb.

Another battery of genes active in the embryo of which diverse representatives are already in hand is that functional in the muscle precursor cells. In addition to the $M$ actin genes (Fig. 2), we have isolated the muscle myosin heavy-chain gene, using a Drosophila probe kindly provided by Dr. Charles Rozek (Case Western University). A significant homology between a region of the Drosophila and the sea urchin gene sequences is shown in Figure 5. As stressed in early considerations of the mechanisms underlying specification of cell type, pleiotropic control of batteries of distinct genes is an essential aspect of developmental gene regulation (e.g., see Morgan 1934; Britten and Davidson 1969, 1971).

Two additional genes that display strict lineage specificity in the early embryo have recently been cloned in our laboratory. In collaboration with Dr. William Lennarz (M.D. Anderson Hospital and Tumor Institute) we have recovered from a $\lambda g t 11$ cDNA clone library several probes for the hyalin gene (J.J. Robinson et al., in prep.). Hyalin is the major component of the tough extracellular coat surrounding the sea urchin embryo, the hyaline layer. This protein can be solubilized by removal of $\mathrm{Ca}^{++}$from the medium, as initially discovered by Herbst (1900). It is stored in the cortical granules of the unfertilized egg, released by exocytosis on fertilization, and from the gastrula stage on is a prominent synthetic product of the embryonic ectoderm cells (Hylander and Summers 1982; McClay and Fink 1982). Its developmental localization is illustrated by indirect immunocytofluorescence in Figure 6, using the antihyalin antibody applied in the detection of hyalin cDNA clones in the $\lambda g t 11$ expression library. Initial ex-

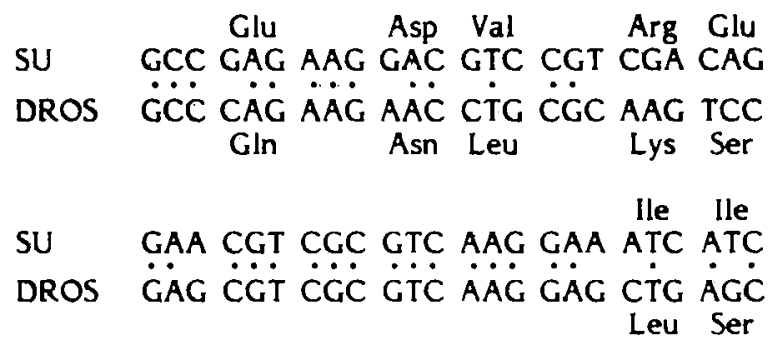

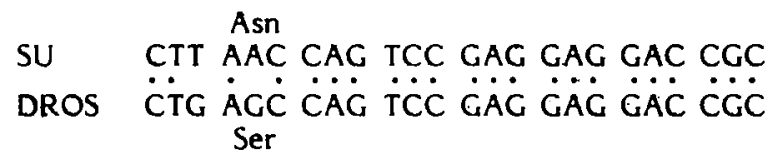

I.le

SU AAA AAT CAC GAA CGA ATC CAG GAT DROS $\ddot{A A G} \ddot{A A C} \ddot{C A C} \ddot{G A G} \ddot{C G C} \ddot{A T C} \dot{C A C} \ddot{G A T}$ Met

Figure 5. Sequence homology between a region of the sea urchin and the Drosophila myosin heavy-chain genes. The region shown derives from a genomic $S$. purpuratus recombinant. Dots indicate identical nucleotides, and where changes result in coding differences the respective amino acids are indicated. In the sequence shown 23/32 amino acids are identical. Drosophila sequence kindly provided by Dr. Sanford Bernstein (pers. comm.). Data from S. Rose, M. Rosenberg, D. Chen, R. Britten, and E. Davidson (unpubl.).

periments with these probes reveal the expected pattern of appearance of hyalin mRNA during development and show that this protein probably consists of crosslinked subunits of about $50-\mathrm{kD}$ mass. We have also isolated from the same $\lambda g t 11 \mathrm{cDNA}$ library a gene for the major spicule matrix protein. The spicules are the $\mathrm{CaCO}_{3}$ "bones" that ultimately provide a structural armature for the larva, and they are synthesized exclusively by primary mesenchyme cells and their descendants. These cells in turn derive from four vegetal pole blastomeres (the micromeres) formed at fourth cleavage. S. Benson, N. Crise-Benson, and F. Wilt (unpubl.) have shown that the protein matrix remaining when spicules are demineralized consists of nine proteins, one of which accounts for $60 \%$ of the total. The gene for this protein has now been cloned and sequenced $(H$. Sucov, S. Benson, J. Robinson, R. Britten, F. Wilt, and E. Davidson, in prep.). This gene is expressed exclusively in primary mesenchyme cells, according to in situ hybridization (S. Benson, H. Sucov, L. Stevens, E. Davidson, and F. Wilt, in prep.). The fate of the micromere-primary mesenchyme cell lineage appears to be determined by localized maternal cytoplasmic factors, and hence the spicula matrix protein gene is of particular interest. Thus, it affords an opportunity to test experimentally the hypothesis that activation of this gene may be caused by interaction with maternal regulators localized initially in the micromeres.

Though knowledge of lineage-specific gene expression in the sea urchin embryo is as yet largely descriptive, an interesting generality has already emerged. This is that specification of the first embryonic cell lineage occurs long before lineage-specific gene expression can 


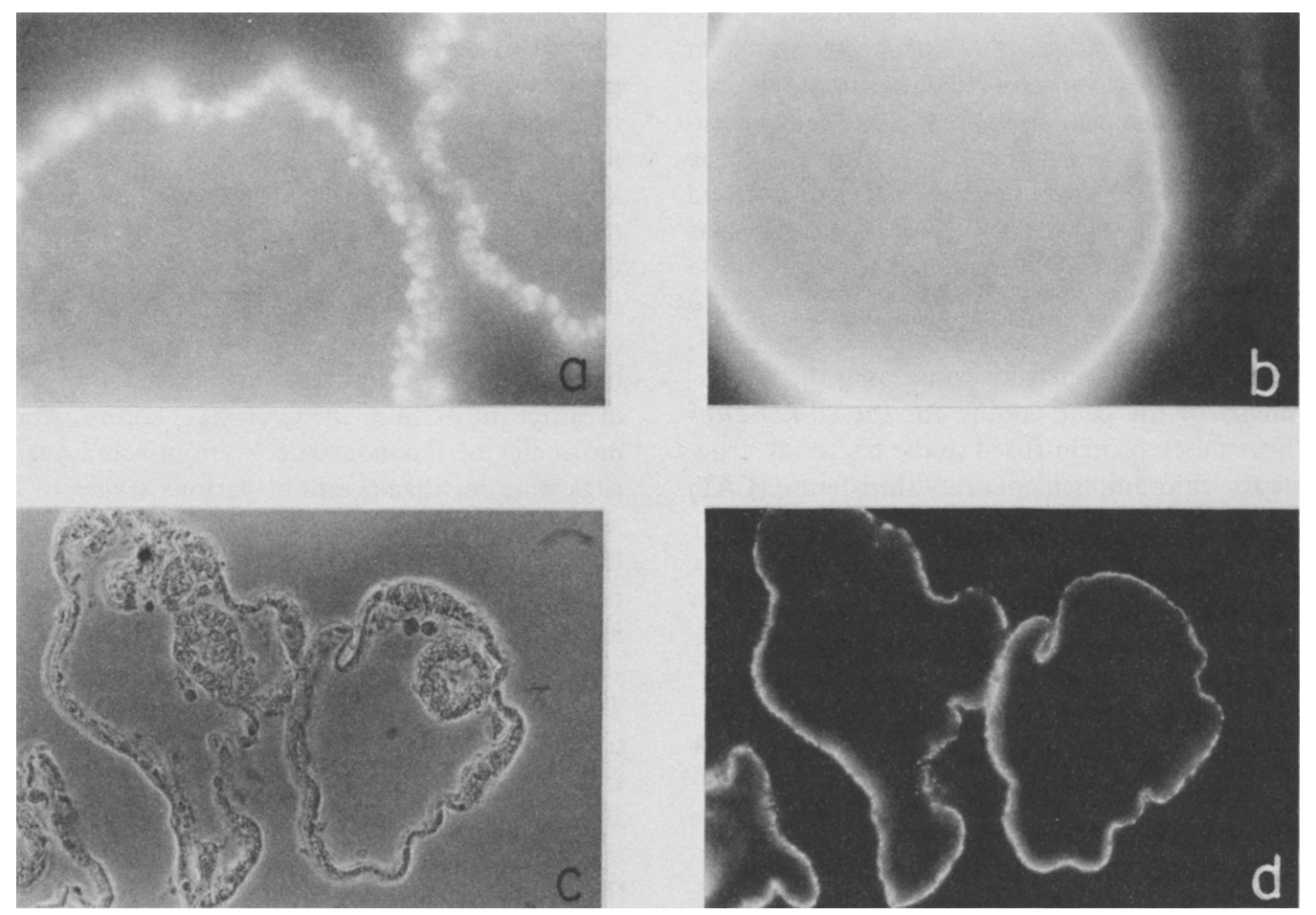

Figure 6. Lecalization of hyalin displayed by indirect immunofluorescence. Pluteus-stage (74-hr) embryos, fertilized eggs, and: unfertilized eggs were fixed, embedded, and sectioned, then reacted with anti-hyalin rabbit antibody. Bound antibody was visualized with fluorescein isothiocyanate (FITC)-conjugated goat antirabbit IgG. (a) Unfertilized eggs. (b). Fertilized eggs. (c) Phase-contrast micrograph of $5-\mu \mathrm{m}$ sections of pluteus-stage embryos. (d). Immunofluorescence from same pluteus-stage embryos as in c. (From J.J. Robinson, N. Ruiz-Bravo, H.M. Sucov, B.R. Hough-Evans, R.J. Britten, W.J. Lennarz, and E.H. Davidson, in prep.)

be detected. By specification is meant the process by which the differentiative fate of the descendants of given blastomeres is first established (whether irreversibly or not is, for this argument, irrelevant). There are only a few "target" nuclei when specification takes place, while expression occurs after a number of divisions have intervened, and a meaningful number of properly situated blastomeres have been produced. Different kinds of mechanisms can be envisioned. For example, genes such as those described here might be activated secondarily by the products of pleiotropically active master regulator genes, which might be the only genes directly affected in the initial specification events. Alternatively, such upper-level hierarchy control genes might not be involved at all in the early development of this embryo, and immediate regulators for the lineage-specific structural genes could be stored in the egg or released by appropriate interblastomere contacts. Specification would then consist of the direct interaction of such regulators with cis-regulatory sequences of lineage-specific structural genes, such as those described in this article.

\section{Gene Transfer: Expression of Microinjected CyIIIa Genes}

We recently described a method for introducing genes into the sea urchin egg by microinjection, and provided evidence that the exogenous DNA is replicated and stably retained during development (Flytzanis et al. 1985; McMahon et al. 1985): Unfertilized eggs are bound by electrostatic attraction to protamine-coated dishes, and several thousand linearized DNA molecules are injected into the cytoplasm of each. Sperm is added, and the eggs develop in situ until hatching, when they secrete an enzyme that dissolves the fertilization envelope, releasing the swimming blastulae. We have shown that within an hour of injection the exogenous DNA has formed random end-to-end concatenates, and during cleavage these replicate an average of 30- to 100-fold. Incorporation of the exogenous DNA into early blastomere nuclei apparently occurs with good efficiency, and the replicated sequences subsequently persist throughout the several weeks of larval life. In about $30 \%$ of larvae, the quantity of exogenous DNA continues to increase. Presumably in these larvae the DNA had originally been incorporated in nuclei of those cell lineages that remain mitotically active during larval growth. In several experiments (see Flytzanis et al. 1985), the genomic DNA of postmetamorphosis juveniles descendant from the injected eggs was examined, and $6-15 \%$ were found to bear integrated sequences. This fraction probably reflects the frequency with which the exogenous DNA is incorporated into cells that are ancestral to the imaginal rudiment from which the postmetamorphosis juvenile de- 
rives. The integrated DNA has been analyzed in cloned isolates from such juveniles, and can be recovered in the DNA of their sperm when sexual maturity has been attained. Such a gene transfer system could thus be utilized to produce transgenic lines of sea urchins. In the experiments described here, however, we have focused on expression of the exogenous DNA in the embryos deriving immediately from the injected eggs.

Initial studies on the expression of DNA injected into sea urchin eggs were reported by McMahon et al. (1984). In this work a construct containing the regulatory elements of the gene coding for the $70-\mathrm{kD}$ Drosophila heat shock protein fused to the bacterial structural gene for chloramphenicol acetyltransferase (CAT) (Di Nocera and Dawid 1983) was injected into eggs by the method described, and the developed embryos were subjected to heat stress. It was found that at $25^{\circ} \mathrm{C}$, a temperature at which the endogenous heat shock response is elicited in this sea urchin species, CAT enzyme synthesis was induced in the host embryos. Since in Drosophila, from which the exogenous heat shock gene sequences derive, this gene is silent at $25^{\circ} \mathrm{C}$, transcription of the injected construct must respond to the diffusible signals produced or activated in the heatstressed sea urchin cells. A similar result has been obtained in other heterospecific studies on Drosophila heat shock gene expression (e.g., Corces et al. 1981). It follows that the exogenous DNA is present in the sea urchin embryo in an intracellular location, and in a form that permits regulated transcriptional expression.

We were thus encouraged to investigate the expression of sea urchin genes that in normal embryos display an easily identified ontogenic pattern of expression. An initial choice was the CyIIIa actin gene, which, as shown in Figures 3 and 4, is expressed in a spatially and temporally specific way. Figure 7 displays the stucture of the in-frame fusion between the CyIIIa gene and the CAT gene that was utilized for the following experiments (C. Flytzanis, R. Britten, and E. Davidson, in prep.). The injected DNA contains several kilobases of upstream CyIIIa sequence, plus a large $(2.2-\mathrm{kb})$ intron wholly included in the $5^{\prime}$ leader of the CyIIIa transcript and coding sequence for only a few of the aminoterminal amino acids of the actin molecule. The remainder of the actin structural gene has been replaced by the CAT gene. Translation could start at either the actin or the CAT ATG codon. About 3000 molecules of this construct were injected per egg, the eggs were fertilized, and at various stages of development aliquots of 20-50 embryos were harvested and the CAT enzyme activity present in the embryos measured. Results from two such experiments are shown in Figure $8 \mathrm{a}$ and $\mathrm{b}$. CAT activity appears essentially on the schedule expected for CyIIIa transcripts (cf. Fig. 4). Thus, by 20 hours the amount of CAT enzyme has attained maximum value. Comparison to an absolute standard for CAT enzyme activity (McMahon et al. 1984) suggests that about $10^{6}$ molecules of CAT enzyme are produced by the CyIIIa-CAT genes per embryo, on the average, and assuming the usual translational parameters (see Davidson 1976) it may be roughly estimated that in the 20-hour embryo the quantity of fusion gene mRNA is on the order of about one-fourth of the natural quantity of CyIIIa message. An important additional observation is shown in Figure 8c. Here is presented a parallel series of experiments in which the upstream regulatory sequences of the $S$. purpuratus early $\mathrm{H} 2 \mathrm{a}$ histone gene (for review of sea urchin histone gene regulation see Hentschel and Birnstiel 1981) have replaced those of the CyIIIa gene in a similar CAT

$1 \mathbf{k b}$
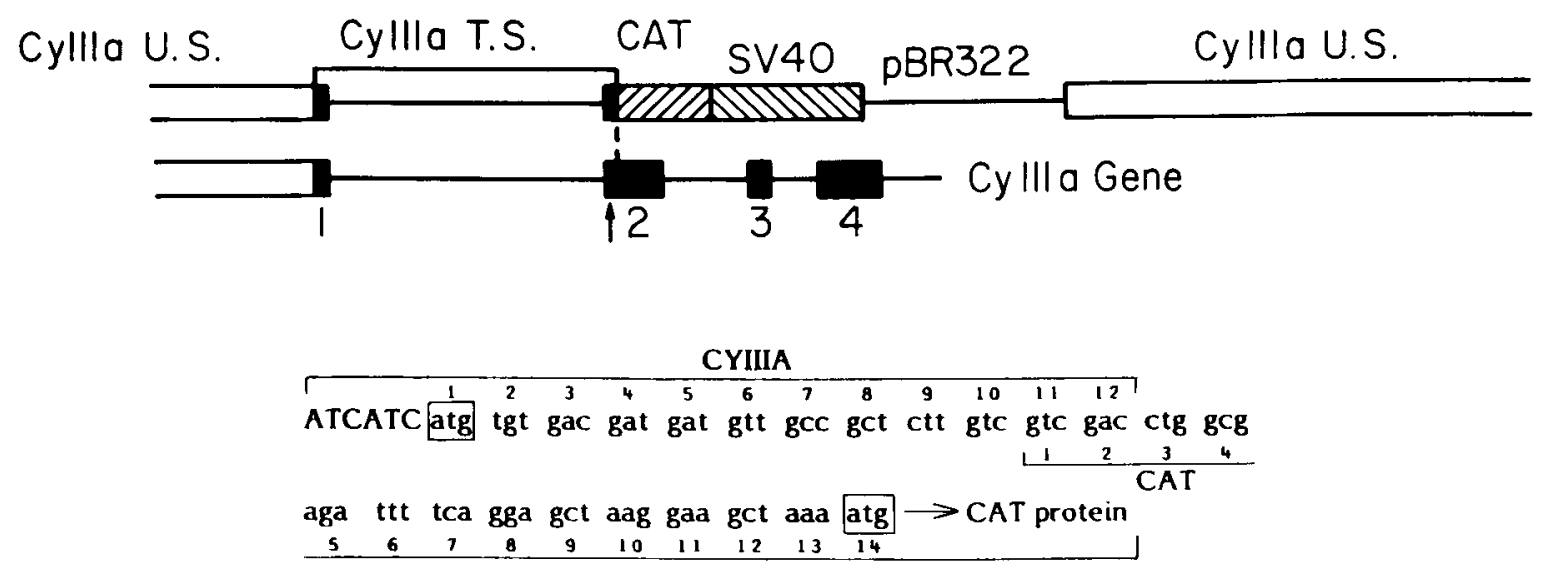

Figure 7. CyIIIa-CAT fusion constructs. (T.S.) Transcribed sequence; (U.S.) upstream sequence. A diagram of the linearized construct as injected into sea urchin eggs is shown in the top line. The plasmid was linearized at an SphI site $2.5 \mathrm{~kb}$ upstream of the $5^{\prime}$ end of the CyIIIa transcript. Since the molecules form a random end-to-end concatenate after injection (McMahon et al. 1985), in half the cases the original 8-kb upstream sequence included in the plasmid will be regenerated. In the second line is a diagram of the CyIIIa gene, from data of R. J. Akhurst et al. (in prep.). Introns are denoted as thin lines and exons are numbered. The third and fourth lines show the sequence of the junction region (shown by the arrow in the second line) between the CyIIIa and the bacterial CAT genes, with the two in-frame ATG translation start codons, the first deriving from the CyIIIa and second from the CAT gene. 


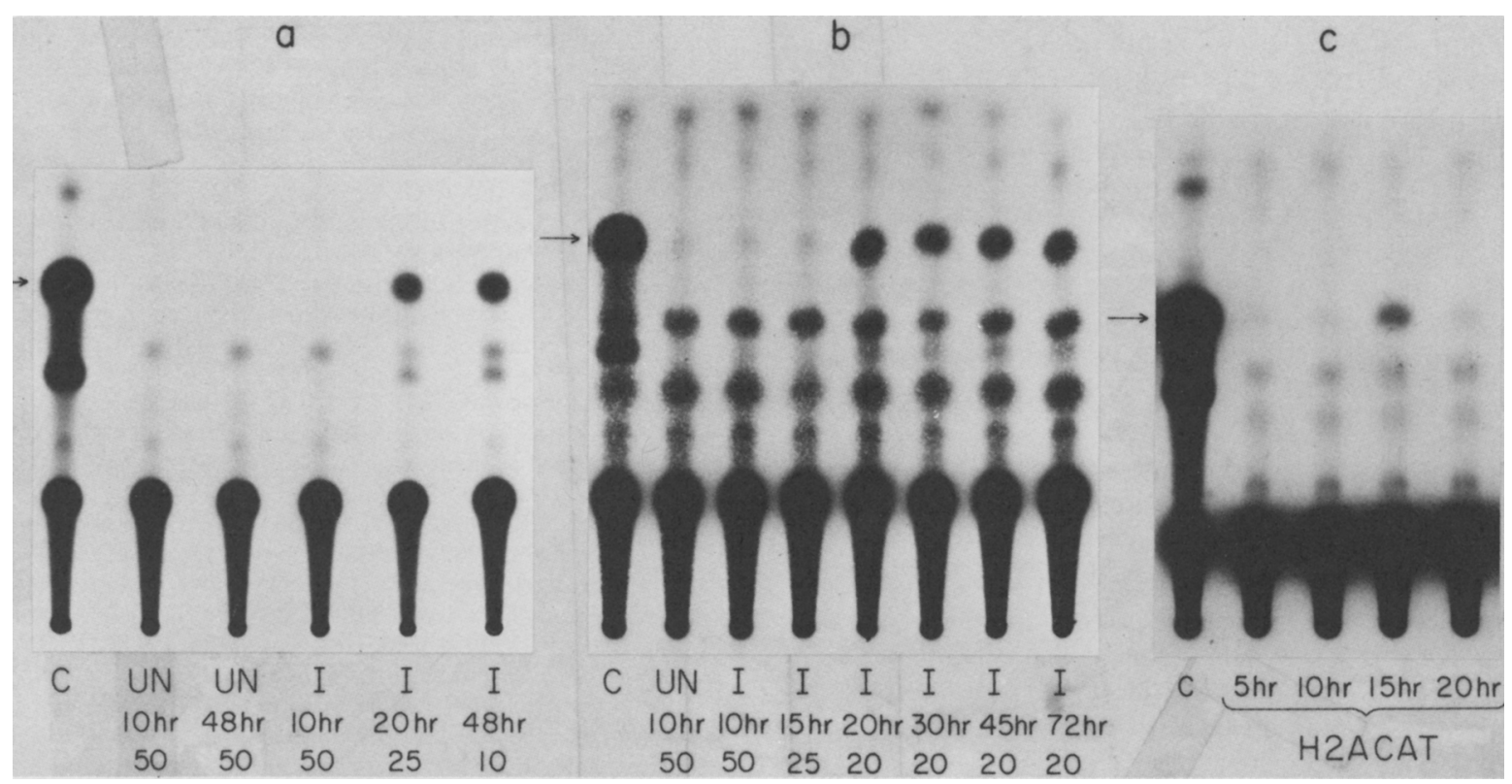

Figure 8. CAT expression from fusion genes injected into sea urchin eggs. The genes were injected into unfertilized eggs which were then allowed to develop until collected for assay of CAT activity, as described by McMahon et al. (1984, 1985; see text). (a and $b$ ) Two independent experiments using the CyIIIa-CAT fusion gene depicted in Fig. 7. (C) Control assay containing bacterial CAT enzyme. The arrow indicates the monoacetylated CAT product. Other samples contained sea urchin embryo extracts. (UN) Embryos derived from uninjected eggs; (I) embryos derived from injected eggs. The number of hours postfertilization and the number of embryos in the sample analyzed are indicated, respectively, in the bottom two rows of numerals. (c) CAT activity in embryos injected with an $\alpha-\mathrm{H} 2 \mathrm{a}-\mathrm{CAT}$ construct. This contained all sequence upstream of the $\mathrm{H} 2 \mathrm{a}$ gene to the preceding $\mathrm{H} 3$ histone gene, but only 30 nucleotides of coding sequence.

fusion construct. In embryos injected with this construct the CAT enzyme appears at 15 hours, just after the amount of endogenous $\mathrm{H} 2 \mathrm{a}$ mRNA reaches its peak value in normal embryos (Mauron et al. 1982).

In preliminary experiments so far available, the CAT activity then disappears, just as does the endogenous $\alpha$-histone message. This result would imply that within the sea urchin embryo the newly synthesized CAT protein is unstable, and also that the mRNA produced by the fusion gene is unstable. The same conclusion follows from the constant amount of CAT activity observed after the blastula stage in embryos injected with the CyIIIa-CAT fusion. Most significantly for the results shown in Figure 8a and b, it is clear from Figure $8 \mathrm{c}$ that the absence of CyIIIa-CAT expression at 15 hours cannot be due to insufficiency of exogenous DNA or inaccessibility of this DNA for transcriptional activation in 15-hour (as opposed to 20-hour) embryos. Some time is required for accumulation of the CAT protein once the message has appeared, and it must also be taken into consideration that injected embryos are delayed in their development by about one division cycle (McMahon et al. 1985). These factors account for the minor retardation, in regard to the respective endogenous transcripts in control embryos, in the appearance of CAT enzyme in both the CyIIIa-CAT and H2a-CAT experiments shown. We may conclude that both the exogenous CyIIIa gene sequences and the exogenous $\alpha-\mathrm{H} 2 \mathrm{a}$ sequences promote expression of their fusion constructs according to the predicted ontogenic schedule.
It should thus be possible to explore directly the mechanism by which lineage-specific genes are activated in the early sea urchin embryo. This is not necessarily the same problem as determining what activates genes in the terminal differentiation processes of later development, or in the physiologically induced genes of adult organisms. The early embryo utilizes spatial regulatory information that originates maternally; it relies to some extent on oriented interblastomere interactions for lineage determination; and, unlike the case in advanced developmental systems, its nuclei are equivalent and totipotent, i.e., until the initial events of lineage specification have taken place. Furthermore, the results summarized by Solter et al. elsewhere in this volume show that some genes destined to function early in mouse development may be "imprinted" at the chromatin level during gametogenesis. The qualitative results illustrated in Figure 8 are already instructive in this respect, however, in that they suggest that genes activated in the early sea urchin embryo respond to trans-activators that are at least initially present in excess. At the level of genomic function, the key to the mechanisms underlying the initial specification of embryonic cell lineages may lie in the nature, origins, and spatial disposition or release of such trans-acting embryonic regulatory molecules.

\section{ACKNOWLEDGMENTS}

This work was supported by National Institutes of Health grants HD-05753 and GM-20927. C.N.F. was 
supported by a Lieve Fellowship (S-11-83) from the American Cancer Society, California Division; J.J.R. by a Proctor \& Gamble Fellowship; S.J.R. by a Muscular Dystrophy Association Fellowship; and H.M.S. and J.J.L. by a National Institutes of Health training grant (GM-07616).

\section{REFERENCES}

Angerer, R.C. and E.H. Davidson. 1984. Molecular indices of cell lineage specification in sea urchin embryos. Science 226: 1153 ,

BRITTEN, R.J. and E.H. DAvidson. 1969. Gene regulation for higher cells: A theory. Science 165: 349.

- 1971. Repetitive and nonrepetitive DNA sequences and a speculation on the origins of evolutionary novelty. $Q$. Rev. Biol. 46: 111.

Bruskin, A.M., A.L. Tyner, D.E. Wells, R.M. Showman, and W.H. KLEIN. 1981. Accumulation in embryogenesis of five mRNAs enriched in the ectoderm of the sea urchin pluteus. Dev. Biol. 87: 308.

BRUSKIN, A.M., P.-A. BEDARD, A.L. TYNER, R.M. SHOWMAN, B.P. BRANDHORST, and W.H. KLEIN, 1982. A family of proteins accumulating in ectoderm of sea urchin embryos specified by two related cDNA clones. Dev. Biol, 91: 317 .

ButLer, E.T. and M.J. Chamberlin. 1982. Bacteriophage SP6-specific RNA polymerase. I. Isolation and characterization of the enzyme. J. Biol. Chem. 257: 5772.

Carpenter, C.D., A.M. Bruskin, P.E. Hardin, M.J. Keast, J. ANSTROM, A.L. TYNER, B.P. BRANDHORST, and W.H. KLEIN. 1984. Novel proteins belonging to the troponin C superfamily are encoded by a set of mRNAs in sea urchin embryos. Cell 36: 663.

Corces, V., A. Pellicer, R. Axel, and M. Meselson. 1981. Integration, transcription and control of a Drosophila heat shock gene in mouse cells. Proc. Natl. Acad. Sci. 78: 7038.

DAVIDSON, E.H. 1976. Gene activity in early development. Academic Press, New York.

Davidson, E.H., B.R. Hough-Evans, and R.J. BRitTEN. 1982. Molecular biology of the sea urchin embryo. Science 217: 17.

Di NocerA, P.P. and I.B. DAwID. 1983. Transient expression of genes introduced into cultured cells of Drosophila. Proc. Natl. Acad. Sci. 80: 7095.

DuRICA, D.S., J.A. Schloss, and W.R. Crain, JR. 1980. Organization of actin gene sequences in the sea urchin: Molecular cloning for a cytoplasmic actin. Proc. Natl. Acad. Sci. 77: 5683 .

Flytzanis, C.N., A.P. McMahon, B.R. Hough-Evans, K.S. Katula, R.J. Britten, and E.H. Davidson. 1985. Persistence and integration of cloned DNA in postembryonic sea urchins. Dev. Biol. 108: 431.

HentSCHEL, C.C. and M.L. Birnstiel. 1981. The organization and expression of histone gene families. Cell 25: 301.

HerbST, C. 1900. Uber das Auseinandergehen von Forchurgs- und Gewebezellen in Kalkfreiem Medium. Wilhelm Roux' Arch. Entwicklungsmech. Org. 9: 424.

Hörstadius, S. 1939. The mechanics of sea urchin development studied by operative methods. Biol. Rev. Camb. Philos. Soc. 14: 132.

HylaNDER, B.L. and R.G. Summers. 1982. An ultrastructural immunocytochemical localization of hyalin in the sea urchin egg. Dev. Biol. 93: 368.

LEE, J.J., R.J. ShotT, S.J. Rose III, T.L. Thomas, R.J. BRITTEN, and E.H. DAVIDSON. 1984. Sea urchin actin gene subtypes. Gene number, linkage and evolution. J. Mol. Biol. 172: 149.

LeV, Z., T.L. Thomas, A.S. LeE, R.C. ANGerer, R.J. Brit TEN, and E.H. DAViDSON. 1980. Developmental expression of two cloned sequences coding for rare sea urchin embryo messages. Dev. Biol. 76: 322.

LyNN, D.A., L.M. ANGERER, A.M. BRUSKIN, W.H. KLEIN, and R.C. ANGERER. 1983. Localization of a family of mRNAs in a single cell type and its precursor in sea urchin embryos. Proc. Natl. Acad. Sci, 80: 2656.

Mauron, A., L. Kedes, B.R. Hough-Evans, and E.H. DavIDSON. 1982. Accumulation of individual histone mRNAs during embryogenesis of the sea urchin Strongylocentrotus purpuratus. Dev. Biol. 94: 425.

MCCLAY, D.R. and R.D. FINK. 1982. Sea urchin hyalin: Appearance and function in development. Dev. Biol. 92: 285.

MCMAHON, A.P., T.J. Novak, R.J. BRITTEN, and E.H. DAVIDSON. 1984. Inducible expression of a cloned heat shock fusion gene in sea urchin embryos. Proc. Natl. Acad. Sci. 81: 7490 .

McMahon, A.P., C.N. Flytzanis, B.R. Hough-Evans, K.S. Katula, R.J. Britten, and E.H. Davidson. 1985. Introduction of cloned DNA into sea urchin egg cytoplasm: Replication and persistence during embryogenesis. Dev. Biol. 108: 420 .

Melton, D.A., P.A. Krieg, M.R. Rebagliati, T. Maniatis, K. ZINN, and M.R. GREEN. 1984. Efficient in vitro synthesis of biologically active RNA and RNA hybridization probes from plasmids containing a bacteriophage SP6 promoter. Nucleic Acids Res. 12: 7035.

MORGAN, T.H. 1934. Embryology and genetics. Columbia University Press, New York.

SChelleR, R.H., F.D. Costantini, M.R. Kozlowski, R.J. BRITTEN, and E.H. DAVIDSON. 1978. Representation of cloned interspersed repetitive sequences in sea urchin RNAs. Cell 15: 189.

SCheller, R.H., L.B. MCAllister, W.R. Crain, D.S. DurICA, J.W. Posakony, T.L. Thomas, R.J. BritTEN, and E.H. Davidson. 1981. Organization and expression of multiple actin genes in the sea urchin. Mol. Cell. Biol. 1: 609 .

ShotT, R.J., J.J. LeE, R.J. Britten, and E.H. Davidson. 1984. Differential expression of the actin gene family of Strongylocentrotus purpuratus. Dev. Biol. 101: 295.

Wallace, R.B., S.K. DuBE, and J. BonNer. 1977. Localization of the globin gene in the template active fraction of chromatin of Friend leukemia cells. Science 198: 1166. 


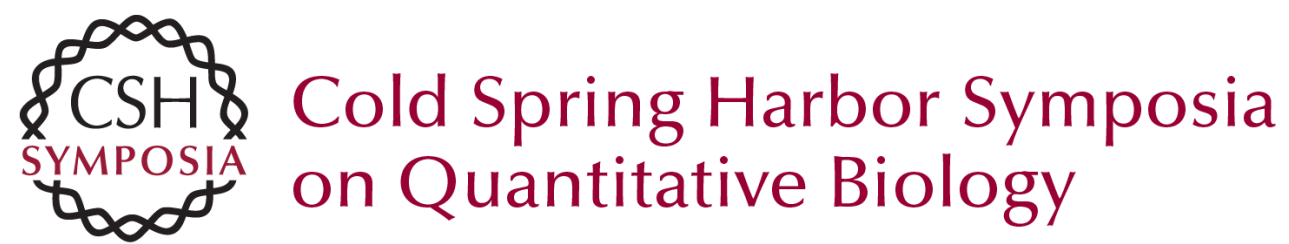

\section{Lineage-specific Gene Expression in the Sea Urchin Embryo}

E.H. Davidson, C.N. Flytzanis, J.J. Lee, et al.

Cold Spring Harb Symp Quant Biol 1985 50: 321-328

Access the most recent version at doi:10.1101/SQB.1985.050.01.041

References This article cites 28 articles, 12 of which can be accessed free at:

http://symposium.cshlp.org/content/50/321.refs.html

Article cited in:

http://symposium.cshlp.org/content/50/321\#related-urls

Email alerting

Receive free email alerts when new articles cite this article service sign up in the box at the top right corner of the article or click here

To subscribe to Cold Spring Harbor Symposia on Quantitative Biology go to: http://symposium.cshlp.org/subscriptions 